Western University

Scholarship@Western

Department of Economics Research Reports

Economics Working Papers Archive

1981

\title{
British Industrialization before 1841: Evidence of Slower Growth during the Industrial Revolution
}

C. Knick Harley

Follow this and additional works at: https://ir.lib.uwo.ca/economicsresrpt

Part of the Economics Commons

Citation of this paper:

Harley, C. Knick. "British Industrialization before 1841: Evidence of Slower Growth during the Industrial Revolution." Department of Economics Research Reports, 8120. London, ON: Department of Economics, University of Western Ontario (1981). 
ISSN:

$0318-725 \mathrm{X}$

ISBN: $\quad 0-7714-0311-9$

\section{RESEARCH REPORT 8120}

BRITISH INDUSTRIALIZATION BEFORE 1841

EVIDENCE OF SLOWER GROWTH DURING THE

INDUSTRIAL REVOLUTION

by

C. Knick Harley

Department of Economics Libray

Nny $\supseteq ? 1981$

University of Western Ontario

November, 1981 


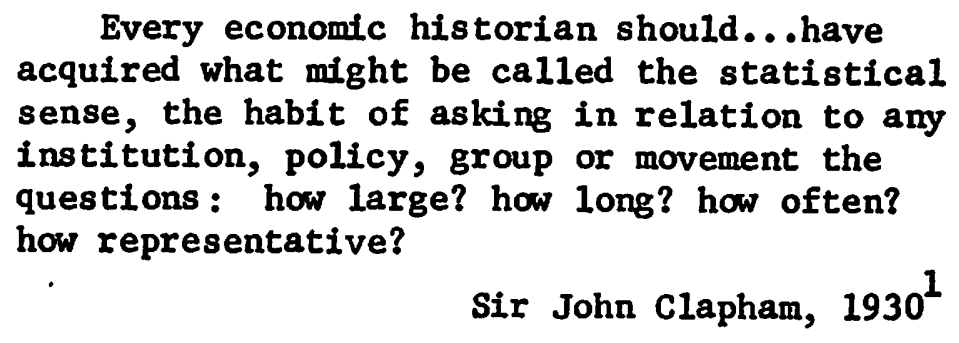

The British Industrial Revolution marks the transition to the modern age. Unfortunately the nature of the transformation that occurred remains obscure, in large part because comprehensive, carefully compiled data do not exist prior to the nineteenth century. With this paucity of data the economic historian must cultivate Clapham's "statistical sense" with special care to avoid over-emphasis of spectacular industrial transformations. This paper presents new indices of industrial output that have been carefully constructed on the basis of the first reliable comprehensive enumeration of British activity--the occupational data from the 1841 Census. Two indices, constructed independently, one with available industry production data and the other with macro-indicators of industrial demand, indicate that industrial growth was nearly a third lower between 1770 and 1815 than either Walther Hoffmann's index of industrial production or Deane and Cole's estimate of aggregate output. ${ }^{2}$ (See Figure 1.) This also implies that the eighteenth century industrial sector was perhaps twice as large as they estimated. The source of these previous over-estimates seems to have been an over-emphasis on the spectacular changes of late eighteenth century. In particular, Hoffman's procedure over-emphasizes the growth of the cotton industry and Deane and Cole's, the growth of overseas trade. 


\section{FIGURE 1}

Various Indices of British Industrial Output, 1700-1841

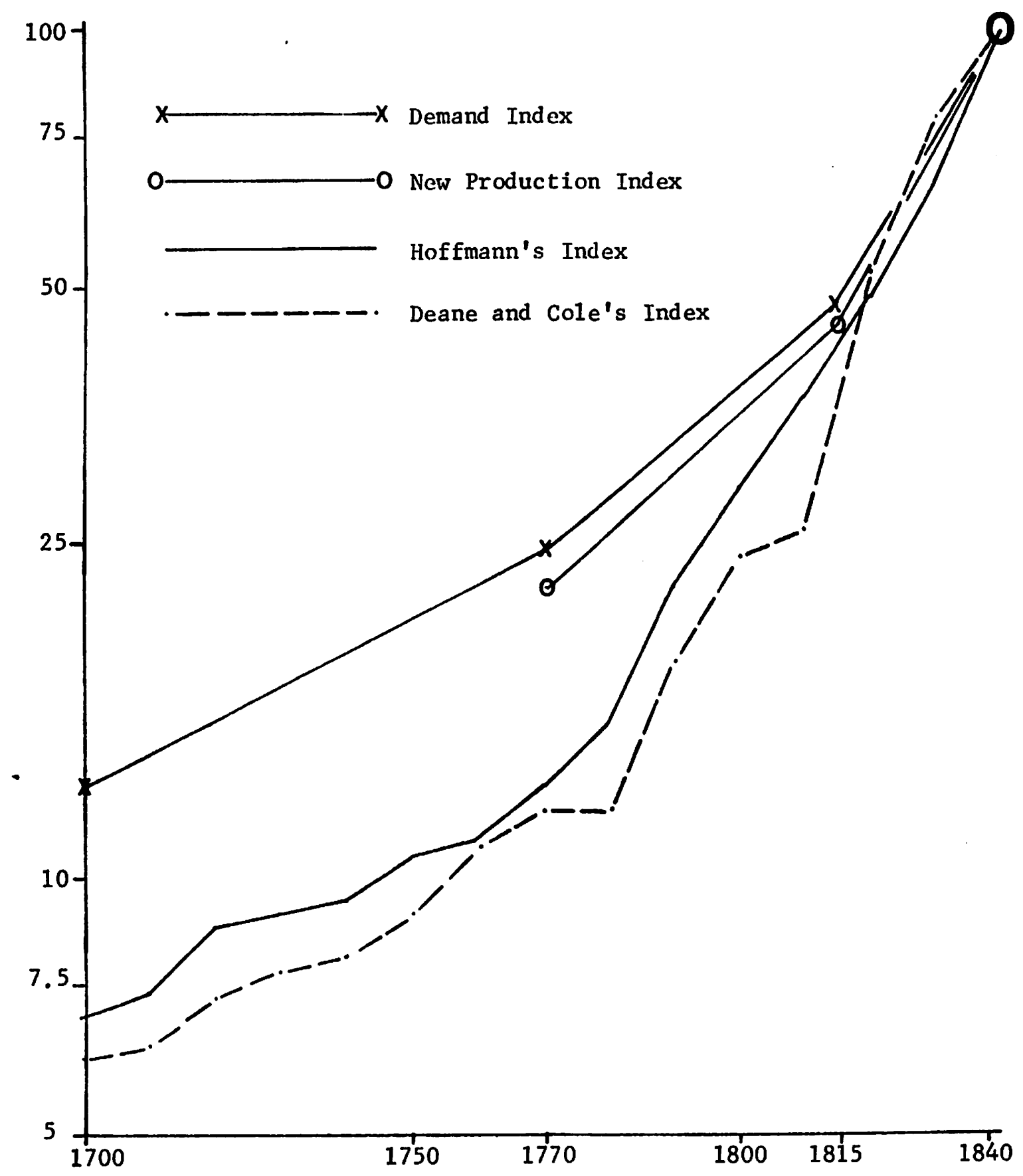


E. J. Hobabawm has recently written "whoever says Industrial Revolution says cotton". One might want to add iron and seam. But these three industries were only a minority--less than a quarter of British manufacturing even in the 1840s, and while their technological transformations have received due attention, they must be kept in proper perspective in a study of British industrialization in the aggregate. The older textile industries of wood, linen and silk and the agricultural processing industries of milling and baking, brewing and distilling, and leather processing certainly generated more income than the technological leaders. The diverse, dispersed and unspectacular industries must all be given proper weight even though the evidence is scant and fragmentary if British industrialization is to be understood.

The diversity of industrial activity was such that realistic estimation of its extent and of the relative importance of its components can only be constructed from systematic enumeration of the economy as a whole. Unfortunately no census of industrial production was conducted in Britain until 1907. It seems likely, however, that the occupational data in the population censuses can provide relatively reliable enumeration by 1841 . Two different and largely independent index numbers are constructed here to chart industrial progress before 1841. The first consists of aggregating various indicators of the growth of specific industries on the basis of weights from the 1841 Census. The second consists of estimating the demand for industrial goods from data on exports, investment, military demand and from estimates of consumption based on controlled conjectures about real wages. 
I. A New Index of Industrial Production

This new index has been constructed from estimates of the output of various industries. Each of these series is uncertain to some degree. Nonetheless, examination of their aggregate implications seems appropriate. With a few exceptions, particularly in the metal industries, these series are very similar to the industry data used in Hoffmann's index. The new index departs significantly from Hoffmann's in devoting systematic attention to consistent weighting. The appropriate weight of cotton textiles, and of iron to a much lesser extent, dramatically influences the growth of the aggregate index. While most industries increased their output by between 40 and 200 percent from 1770 to 1815, and by between 33 and 150 percent from 1815 to 1841 , cotton output increased twenty-threefold in the first period fivefold in the second and iron production by 350 percent and by 250 percent.

The only appropriate means of determining appropriate weights is to rely on a comprehensive enumeration of production that originated independently of contemporaries interest in the novel and the visible. The occupational classification from the 1841 Census is the first rellable systematic enumeration of this sort. The data in the four earlier censuses are, unfortunately, insufficiently comprehensive or reliable to permit the construction of an earlier benchmark.

\section{A. The Structure of British Industry in 1841}

The weighting scheme that has been employed in producing an output index (see Table 1 ) is a slight modification of the distribution of labor among industrial occupations as reported in the census. The modifications consist of assigning half the weight of adult males to both women, and children and youths ("under 20 years of age" in census returns). This weight roughly 
TABLE 1

Weighting of Various Industrial Sectors, $1841,1815,1770$

$\begin{array}{llll}\text { Industry } & 1841 & \underline{1815} & \underline{1770} \\ \text { Textiles } & & & \\ \text { Cotton } & .10 & .08 & .01 \\ \text { Wool } & .08 & .11 & .15 \\ \text { Linen } & .04 & .06 & .08 \\ \text { Silk } & .03 & .02 & .04 \\ \text { Clothing } & .13 & .12 & .11 \\ \text { Leather } & .11 & .14 & .19 \\ \text { Metal } & .11 & .08 & .05 \\ \text { Food and Drink } & .04 & .06 & .08 \\ \text { Paper and Printing } & .02 & .02 & .01 \\ \text { Mining } & .08 & .08 & .05 \\ \text { Building } & .18 & .15 & .12 \\ \text { Other } & . & .09 & .12\end{array}$

Source: See text. 
approximates the wage structure in cotton mills. If there is a bias in this procedure it is toward overweighting women and youths. This, in turn, would overweight textiles, particularly cotton, and clothing. In addition, the 110,031 adult males returned as "weaver (branch not specified)" were also assigned half the weight of other adult males to reflect the low wages of the hand-loom weavers.

The data were aggregated into industrial classification by Charles Booth. ${ }^{4}$ His textile total has been distributed among cotton, wool, linen and silk on the basis of Deane and Cole's net output estimates. 5 A second adjustment to Booth's data transferred the census 214,780 "Boot and Shoemakers" from "Dress" to "Fur, Leather, Glue, etc." The resulting employment weights for 1841 are presented in Table 1.

If data were available, value added which allows for inter-industry differences in wages and in capital income would provide more satisfactory weights. In the absence of comprehensive enumeration of these differences, however, there are no clear rules for adjusting the employment data. If adjustment could be made the weight of the metal industries would probably increase modestly, although care must be exercised since the industry included the very low paid nail makers and others in the Black Country finishing trades. The food processing industries would probably increase in weight since milling, brewing and distilling were among the most capital intensive industries of the time. On the other hand, the low paid and modestly capitalized clothing and leather industries probably had a smaller share in value added than in employment. The weight on cotton textiles is by far the most important for the index since the growth of this industry was so much more rpaid than that of any other. Fortunately, there does not seem to be any reason why this industry's relative value added should be far from its relative employment share. 
B. Estimates of Structure for 1815 and 1770 :

Adjustment for Relative Price Change

The outstanding features of the Industrial Revolution were, of course, the technological revolution in cotton and iron that radically altered the prices of these goods relative to other prices in the economy. These price changes imply that the relative value of the products of various industries will be altered over time, not only because physical output grew at different rates but also because relative prices changed. These relative values generated by both price and quantity changes reflect the actual pattern of resource allocation at various dates and any comprehensive exercise at index number construction must take this price effect into account by employing weights at various base periods. Since no comprehensive data exist for earlier benchmarks, it is necessary to use relative price data to make rough adjustments to the relative shares projected from the 1841 benchmark by quantity data. This has been done for 1770 and 1815 and the results are presented in Table 1 .

The weights for 1815 and 1770 reflect simple projection of the 1841 weights by the physical output indices for all industries except cotton and iron. The exact magnitude of the change in the relative prices of even these two industries cannot be precisely determined. For cotton, the 1815 relative price has been taken to have been twice its 1841 level. This estimate is based principally on Lars Sandberg's work. Sandberg's index of gray cloth prices falls to 29 from an 1815 base of $1000^{\circ}$ Rousseaux's index of industrial prices fell to 67 on the same base, implying a real price decline of cotton gray cloth to 43. Gray cloth, however, was an intermediate output of the cotton textile Industry and finishing roughly doubled the value added in gray cloth. ${ }^{7}$ Technological progress in fintshing was slower 
than in the transformation of raw cotton to gray cloth. The best available indicator of this effect seems to be change in the relative export value of gray and finished cloth. Sandberg finds that the average value of finished cloth rose twenty eight percent relative to gray cloth. 8 If this is interpreted as a relative price movement, it implies that the price of finished cotton goods relative to other manufactured goods was 55 percent of its 1815 level in 1841.

Fortunately, reasonable alternative weights do not alter the general tenor of the index of industrial production. If prices are assumed to have been fifty percent higher in 1815 rather than twice as high, the growth of the index with 1815 weights changes by less than one-tenth of a percent a year both between 1815 and 1841 and between 1790 and 1815 . If the 1815 weights, assuming that the relative price of cotton was three times the 1841 price, generates growth rates that are increased by one- or two-tenths of a percent per year, from a range of 1.5 to 1.6 percent a year from 1770 to 1815 to a range 1.6 to 1.7 and for 1815 to 1841 from a range of 3.2 to 3.3 to a range of 3.4 to 3.5 . Surely these are hardly significant changes given the quantity of the data.

The cotton price trend from 1815 to 1841 is assumed to continue back to the turn of the century but not beyond. ${ }^{9}$ This implies that cotton textile prices in 1770 were fifty percent higher than in 1815 and three times the 1841 level. The volume of cotton was so small by 1770 that modestly different assumptions have little effect. Even doubling the estimated price of cotton goods to six times the 1841 price would only increase the 1815 output index by ten percent and the annual growth rate from a range of 1.6 to 1.7 to a range of 1.8 to 1.9 . 
The 1815 and 1770 bases also incorporate the declining price of iron. Here, just as with gray cloth, care must be taken to avoid attributing the price decline of an intermediate good, in this case pig or bar iron, to the final product. The final stages of production of iron added value at least equal to the value of the bar iron used in its construction. A calculation based on Charles Hyde's estimates of cost improvement in bar iron production ${ }^{10}$ with a weight of one-half and assuming that the finishing processes did not fall in price relative to other manufacturing, suggests that real iron costs were not more than 1.2 times their 1841 level in 1815 nor above 1.8 times their 1841 level in 1770. These values have been used In the reweighting.

\section{Indices of Output of Various Industries}

The indices of output of various industries have, with the principal exception of iron output, been compiled from standard series. These include trade and excise data and contemporary estimates. Any particular series is subject to considerable uncertainty and the original sources should be consulted. Index values for 1770 and 1815 are presented in Table 2. The sources of the various series are presented in Table 3.

The metal production series requires more discussion. The series is based on the data for the iron industry and attempts to estimate final output. Pig or bar iron production cannot be used without modification because these are intermediate products that were largely imported in 1770, but domestically produced by 1815. Pig iron production and bar iron imports have been adjusted to final product estimates on the basis of the relative price of pig and bar iron and on the ratio of raw material purchases to final value from the American Census of 1840 . 
TABLE 2

Indices of Output by Industry, 1770, 1815, 1841

$$
1841=100
$$

Industry
Cotton
Wool
Linen
Silk
Clothing
Leather
Metal
Food and Drink
Paper and Printing
Mining
Building
Other

1770

0.8

46

47

28

20

41

7

47

17

15

16

15-50
1815

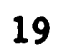

65

75

40

43

61

29

69

47

46

42

$40-60$ 
TABLE 3

Sources of Industrial Output Series

Series

1. Cotton:

2. Wool:

3. Linen:

4. Silk :

5. Clothing:

6. Leather:

7. Metal:

8. Food and Drink:

\section{Paper and} Printing:

10. Mining:

11. Building:

12. Other unenumerated industries :

\section{Construction of Series}

5-year centered average of retained cotton imports

Sum of estimated domestic clip and imports

Deane and Cole's estimate

Deane and Cole's estimate

Terminally weighted aggregate of textile output adjusted for exports of cotton and wool.

5-year centered average of excise data extended to 1814 by Hoffmann data

See Text

Average with equal 1841 weights of population growth as an index of milling and baking and a 5-year average of the beer excise 1770-1815 and the average of the excise series for hops and malt thereafter

5-year average of excise data

Estimates of coal production

Sum of Feinstein's estimates of "dwellings," "public buildings and works," "industrial and commercial buildings," "railways," "roads and bridges," "canals and waterways," "docks and harbours" and half of "agricultural investments".

A range has been allowed that spans the range for the other industries except cotton and metal.
Source

Mitchell, British Historical Statistics, pp. 177-179. Miche11, British Historical Statistics, pp. 190-192.

Deane and Cole, British Growth, pp. 202-205.

Deane and Cole, British Growth, pp. 207-210.

Mitchell, British Historical Statistics, p. 266. Hoffmann 1955, Table 54, series 50.

Ron Lee, "Population," in D. N. McCloskey and Roderick Flood, New Economic History of Britain (Cambridge:

University Press, 1981).

Mitche11, British Historical Statistics, p. 263.

S. Pollard, "A New Estimate of British Coal Production 1750-1850," Econ. Hist. Rev., XXXIII (May 1980), p. 229.

C. H. Feinstein, "Capital Formation in Great Britain," in Cambridge Economic History of Britain, Vol. VII, pt. 1, p. 40 . 
The relative prices of $\mathrm{pig}$ and bar iron combined with the conventional rates of $30 \mathrm{cwt}$. of pig iron to produce a ton of bar iron indicate that a ton of pig iron converted into two-thirds' ton of bar iron that was worth 1.6 tons of pig iron. The U.S. Census data for the ratio of final value to raw material costs for several iron-using industries are presented in Table 4 below. The aggregation that has been adopted assumes that final stages of manufacturing double the value of the bar iron. That is to say, each ton of pig iron became worth the equivalent of 3.2 tons of pig Iron after it had been transformed into manufactured iron products. Similarly, a ton of imported bar iron had a value equal to 2.4 tons of pig and the domestic manufacture of that iron added an equal value. The assumption that final output was worth twice the value of the bar iron has the dubious virtue of simplicity. If anything it is probably a low conversion factor. The result of a low conversion on the series is to lower the estimate of output in 1770, when imports of bar iron were substantial relative to that of later years. This increases the growth rate of the series.

A substantial proportion of domestic pig iron was cast into final products. These have been estimated at a quarter of domestic pig iron production in 1775, forty percent in 1815 and a quarter in $1841 .^{11}$ This output is valued at 1.25 times the value of pig iron. Calculations of output for 1775,1815 and 1841 are presented in Table $5 .^{12}$ 
TABLE 4

Ratio of Final Value of Output to Raw Material Costs,

Various American Industries 1839

Nails

1.7

Stoves

2.1

Hardware and Miscellaneous

Iron Manufactures

2.3

Cutlery

2.6

Clocks

2.8

Blacksmiths

3.2

Guns

4.3

Source: U.S. Census, 1840, pp. 137-142. 
TABLE 5

Iron Output in Pig Iron Equivalent Units: 1775,1815 and 1841

\begin{tabular}{|c|c|c|c|c|c|c|}
\hline \multirow[b]{2}{*}{ Production of: } & \multicolumn{2}{|c|}{1775} & \multicolumn{2}{|c|}{1815} & \multicolumn{2}{|c|}{1841} \\
\hline & '000 tons & $\begin{array}{l}\text { Pig Iron } \\
\text { Units }\end{array}$ & $' 000$ tons & $\begin{array}{l}\text { Pig Iron } \\
\text { Units }\end{array}$ & $' 000$ tons & $\begin{array}{l}\text { Pig Iron } \\
\text { Units }\end{array}$ \\
\hline Pig Iron & 44 & & 395 & & 1396 & \\
\hline Cast Iron & 11 & 14 & 158 & 198 & 349 & 436 \\
\hline $\begin{array}{l}\text { Exports as Pig } \\
\text { Manufactured Bar a } \\
\text { Iron }\end{array}$ & -- & -- & & 30 & & 540 \\
\hline $\begin{array}{l}\text { Manufactured Iron } \\
\text { From Domestic Pig }\end{array}$ & $\stackrel{33}{(o f} \mathrm{Pig})$ & 105 & $\begin{array}{l}210 \\
(\text { of } P 1 g)\end{array}$ & 672 & 677 & 2166 \\
\hline $\begin{array}{l}\text { Manufactured Iron } \\
\text { From Imported Bar }\end{array}$ & 47 & 113 & & -- & & $\cdots$ \\
\hline Total & & 232 & & 900 & & 3142 \\
\hline
\end{tabular}


TABLE 6

Various Indices of Industrial Production

A. Index with 1841 Weights

1841

1815

1870

B. Indices for 1815-1841

Laspeyres (1951 base)

Paasche (1841 base)

Fisher's Ideal

Divisia

C. Indices for 1770-1815

Laspeyres ( 1770 base)

Paasche (1815 base)

Fisher's Ideal

Divisia

D. Hoffmann's Index

1841

1815

1770
Index

100

45-47

22-25

Index $(1815=100)$

229-237

212-221

220-229

219-228

Index

$(1770=100)$

208-220

197-206

202-213

198-209

Index

100

43

14
Annual Growth Rate

$$
2.9-3.0
$$$$
1.4-1.6
$$

Annual Growth Rate

$3.2-3.3$

2. $9-3.0$

3. 0-3.2

$3.0-3.2$

Annual Growth Rate

1.6-1.7

$1.5-1.6$

1.5-1.7

$1.5-1.6$

Annual Growth Rate

$$
3.2
$$$$
2.6
$$ 


\section{Indices of Industrial Production}

There is no uniquely correct method of constructing a quantity index when relative prices are changing. It seems most appropriate therefore to calculate and present a series of indices using various appropriate weights. These various index numbers are presented in Table 6 . The first index is based on the 1841 industrial weights and extended back to 1770 . In addition, indices have been constructed for the subperiods 1815 to 1841 and 1770 to 1815 using varlous weights. The Laspeyres indices use initial weights and will normally overstate the growth rates. Conversely, the Paasche index with terminal weights will understate growth. In addition, Fisher's Ideal index number which is the geometric mean of the Paasche and the Laspeyres' Index and a discrete approximation of a Divisia in which the growth rate of the index is calculated as the weighted sum of the growth rate of the components, with the weights being the geometric

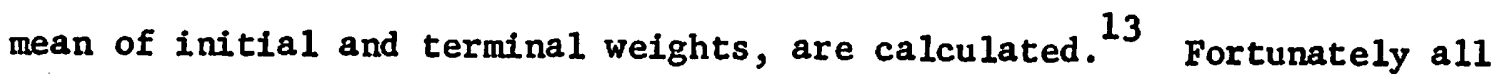
four Indices fall within a fairly narrow range of values.

\section{E. Comparison with Hoffmann's Index}

Walther Hoffmann's index, since its construction in the late 1930s, has been the accepted index of British industrial production. Hoffmann's index is included in Table 6 for comparison with the present indices. The indices constructed here and Hoffmann's index are in substantial agreement for the period from 1815 to 1841, but there is very substantial disagreement for the period 1770 to 1815. This 1s, of course, the period of the classical Industrial Revolution. The new indices estimate that the annual growth rate of industrial output was a full percentage point lower than Hoffman calculated. Consequently, Industrial output was more than fifty percent greater in 1770 than Hoffmann's index indicates. A disparity of this magnitude requires exploration. 
The divergence between the new industrial production indices and Hoffmann's index arises almost entirely from the excessive weight that Hoffmann assigned to cotton and iron in the 1783 base that he used to construct his index between 1761 and 1800. Hoffmann's data and various weighting schemes are presented in Table 7 . The growth rates of the components of Hoffmann's index are not significantly different from those presented above. If these components are aggregated using the 1815 and the 1770 weightings presented in Table 1, the index takes on values $(1770=100)$ of 198 and 219 implying annual growth rates of 1.5 and 1.7 percent. These values fall within the range of values for the new indices in Table 6 .

Hoffmann's index over this period utilizes 1783 weights until 1800 and then 1812 weights; the two Indices are chained on their 1800 values. It is readily apparent, however, that the 1783 base is the principal source of Hoffmann's calculation of rapid growth during the industrial revolution period. In that base year Hoffmann estimated that cotton textiles contributed 6.7 percent of industrial output and iron, 6.5. However, the sum of the weights of the Industries for which he had data made up only 56.4 percent of total value added, thus cotton and iron both have a weight of 12 percent in the index $\left(\frac{6.7}{.56}=12.0\right) .{ }^{14}$ This procedure is in effect assuming that the growth experience of other industries was comparable to the weighted growth of the included industries. It certainly seems unlikely that 12 percent of the uncounted industries had a growth as rapid as cotton and another 12 percent a growth comparable to iron. The weights in Hoffmann's 1812 base are also increased because of the limited industrial coverage of the data. The weights for cotton and iron are increased from 12.2 and 9.2 to 15.9 
TABLE 7

Exploration of Hoffmann's Index 1770-1815

I. Hoffmann's Output Indices $(1770=100)$

\begin{tabular}{lrrr} 
& Cotton & Iron & Other \\
\cline { 2 - 4 } 1783 & 283 & 196 & 101 \\
1812 & 2433 & 586 & 155 \\
1815 & 2600 & 618 & 172
\end{tabular}

II. Aggregation With Weights From Table 1
Weights
Index $1770=100$
Rate of

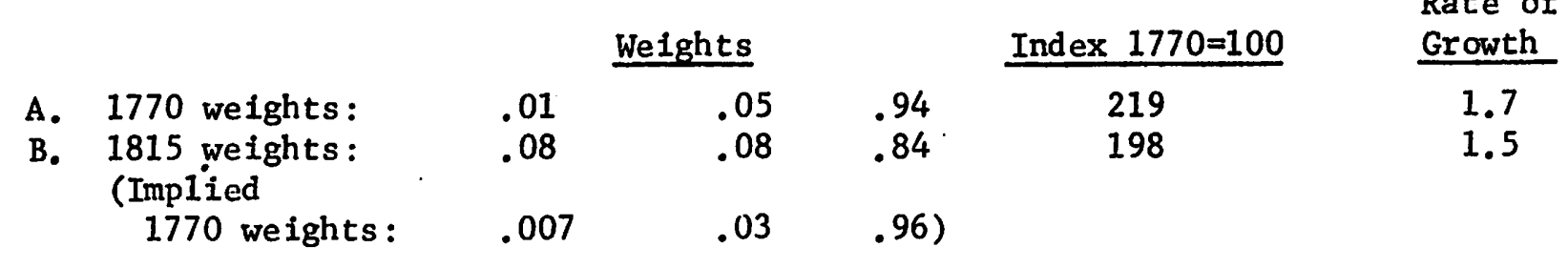

III. Hoffmann's Weights (Weights inflated for missing series)
A. 1783 weights: $\quad .12$
$.12 \quad .76$
326
2.6
(Implied

$.05 \quad .07 \quad .88)$
B. 1812 weights : $\quad .16 \quad .12 \quad .72$
(Implied
1770 weights : $\quad .01 \quad 04 \quad .95)$
223
1.8

IV. Modified Hoffmann Weights (weight of missing series assigned to "other")
A. 1783 weights : $\quad .07$
(Implied
.07
.86
257
2.1
$.04 \quad .93)$
B. 1812 weights: $\quad .12$
$.09 \quad .79$
207
1.6
(Imp1ied
$.03 \quad .96)$ 
and 12.0 respectively. A preferable alternative to Hoffmann's procedure of increasing weights proportionately would be to assume that excluded industries grew at the rate of the industries other than cotton and iron. Such calculations are presented in panel IV of Table 7. Hoffmann's 1783 weights still produce an excessively rapid growth but his 1812 weights present results that are equivalent to those in Table 6 . In order to compare the various weighting schemes it is necessary to examine the weights implied for a common year. Implied weights in 1770 seem an appropriate basis for comparison and they are presented in Table 7. Recall that the 1770 weights from Table 1 were explicitly calculated from the 1841 census employment shares, volume of output estimates and the assumption that the price of cotton was three times as high in 1770 as in 1841 relative to other industrial prices and that iron prices were eighty percent higher in 1770 than in 1841 . If the 1841 shares and the volume estimates are accepted--and here Hoffmann's data are not greatly different from my own-then the weight of five percent that Hoffmann's index, with its 1783 base, assigns to cotton in 1770 ,implies that 1783 cotton prices relative to other industrial goods prices were some 16 times as high as they were in 1841 . Just comparing Hoffmann's 1812 and 1783 bases implies a relative price of cotton five times as high in 1783 as 1812. These price movements seem at variance with most careful assessments of the cotton industry. An alternative explanation of Hoffmann's 1783 weights, that cotton prices were about eight times as high as they had been in 1841 and that other industries, in aggregate only slightly smaller than cotton textiles, shared cotton's price and quantity experience in the late eighteenth century, is even more unlikely to be true. It seems fair to conclude that the rapid growth that Hoffmann's industrial production index shows for late eighteenth century is a distortion created by the weighting procedure he employed between 1761 and $1800 .^{15}$ 
II. The Demand for Industrial Products, 1700-1841

Since profitable production requires purchasers for the goods produced, estimation of the growth of demand provides an alternative approach to an index of industrial output. The data that are used to produce this estimate are as imperfect as other aggregate data prior to the systematic censuses of the mid-nineteenth century. Somewhat paradoxically, the very imperfection of the data provides a rationale for the construction of a demand index. The "statistical sense" that Clapham urges invites independent estimation of alternative measures whenever possible. The confidence that can be placed on estimates of the structure and growth of industrial production is greatly strengthened if independent estimates produce similar and mutually consistent pictures of the economy. An estimate of demand for industrial output can be projected from 1841 into the 18th Century on the basis of estimates of investment, official data on trade and military expenditure and inferences about consumption drawn from studies of real wages. An estimate so constructed shows a striking conformity with the index of industrial production presented above. In addition, between 1770 and 1815 this demand index agrees with the new indices in Table 6 by being strikingly at odds with the estimates of very rapid industrial growth produced by Hoffmann and Deane and Cole.

Estimation of the growth of demand for industrial products also provides insights into the nature of the growth of British industry. Several economic historians have suggested that the growth of demand was an important aspect of British industrialization, and even a cause of economic growth more broadly defined. $^{16}$ Recently some economists have challenged the latter point. ${ }^{17}$ In particular, Joel Mokyr has argued that there are compeling theoretical and 
empirical reasons to believe that output was limited by the supply constraints of technological knowledge and the availability of factors of production. Even though Mokyr's description of the growth process as constrained by supply forces is undoubtedly correct, he has dismissed an important line of approach by his rejection of the usefulness of the "Gilboy Thesis" that thinking about demand helps in "making sense of the Industrial Revolution". Certainly a failure to recognize the difference between economic growth in the aggregate and industrialization has confused much of the economic history of Britain from 1750 to 1850 ,but explanation of industrial growth will clarify that history and here consideration of the structure and growth of demand has an important role. Much of the growth of many industries resulted not from technological change within the industry but from a change in the composition of production in response to growing income, increased investment and growing colonial population. The estimation of an index of industrial demand provides a quantification of this process.

\section{A. The Structure of Industrial Demand}

The demand for industrial products arose from the final demand of consumers, demand for investment, demand' for exports and from military expenditure. Estimates of the relative importance of these components for 1841 and 1770 are presented in Table 8. As in construction of the industrial production index above, the benchmark based on the 1841 census is regarded as the earliest reliable estimate of the industrial sector. Deane and $\mathrm{Cole}^{18}$ estimate the income originating in industry in 1841 at $\$ 155$ million. Since there are data on the value of exports ( $\$ 50$ milition) and careful 
estimates of investment ${ }^{19}$ ( $\$ 45$ million). The share of these components can be relatively easily estimated. There are, nonetheless, pitfalls. Deane and Cole's estimate is of income originating in industry while the exports and investment data are values of final product. Data from American censuses 20 indicate value of final sales was about twice the income originating in the sector. Thus exports represent $16 \%$ of demand and investment $14 \%$.

Consumption cannot be estimated directly but must be estimated as a residual. Military expenditures generally were quite small and could probably have been ignored had they not become a very large proportion of national income in the late years of the Napoleonic Wars. Between 1812 and 1815 military expenditures were over $\$ 55$ million annually or about 18 percent of Deane and Cole's national income estimate. It is difficult, without a full study of military expenditure during the war, to allocate this to its various components. $^{21}$ A very substantial proportion, in any event, went to the provisioning of armies overseas. In 1810 the commissary for Wellington's 35,000 troops in the Penninsula appears to have cost close to $\$ 400,000$ per month. 22 These troops were about one-third of the active forces and their provisions appear to have cost about one-quarter of the army's total expenditure. It seems likely that basing calculations on an assumption that half the military expenditures were for British produced manufactured goods will, if anything, exaggerate the role of the military. The indices are constructed on this assumption.

Fortunately, estimation of the growth of demand for industrial products over most periods is not very sensitive to modest changes in the weighting of the components. Unfortunately, the single exception to this statement occurs at the end of the Napoleonic Wars when the level of the index is quite sensitive 
to the weighting of the military budget.

Relative price changes will, of course, alter relative weights here as they did in the industrial production index. The important price change occurred in exports relative to other uses of manufactured goods. In 1841 cotton textiles, the good whose price had fallen most dramatically, made up 45 percent of domestic exports but only 10 percent of industrial output. 1770 weights have been calculated using the quantity indices discussed below and the assumption that relative export prices were two-thirds above their 1841 level.

\section{B. The Component and Aggregate Indices}

Consumption was by far the largest component of demand and unfortunately the component about which we know least. An index of consumption expenditure has been constructed from plausible estimates of real wage levels and labor force size and a plausible income elasticity of demand. Real wage estimates are, of course, notoriously unreliable and controversial prior to the midnineteenth century. From 1815 to 1841 the data surveyed by M. W. Flinn and G. N. von Tunzelmann ${ }^{23}$ suggest an increase in average real wages of about onethird. The consensus seems to be that real wages were stagnant from 1770 to 1815. From 1700 to 1770, E. W. Gilboy ${ }^{24}$ offers guidance and suggests an average increase of one-quarter. Labor force growth has been assumed to follow population growth, ${ }^{25}$ except in 1815 when labor force is reduced by seven percent to allow for the nearly 500,000 men serving in the military during the last years of the Napoleonic Wars. These income estimates are converted to demand for industrial comodities on the assumption of an income elasticity 
TABLE 8

Structure of Industrial Demand, 1841 and 1770

$\begin{array}{lcc} & 1841 & \underline{1770} \\ \text { Consumption } & 68 & 77 \\ \text { Exports } & 16 & 13 \\ \text { Investment } & 14 & 7 \\ \text { Military } & .2 & 3\end{array}$

Source: See text. 
of demand of $1.4 .^{26}$ These results are presented in the top panel of Table 9. Indices for investment, exports and military are straightforward. They and their sources are present in the lower panel of Table 9 along with indices of industrial demand.

\section{Comparison with Other Indices}

These indices of demand provide a gratifying degree of support to the independently estimated indices of industrial production calculated above. The demand index for 1815 is somewhat high relative to the production index while the values for 1770 fall within the range calculated from production data. The discrepancy in 1815 is not great considering the nature of the data. The discrepancy could arise from an overweighting of military expenditure or from modest underestimation of wage trends.

The post-Napoleonic War growth also is compatible with Hoffmann's index for that period. A major disagreement again arises between the demand estimate and Hoffmann's index between 1770 and 1815. Hoffmann's index grows at a rate of 2.6 percent a year while the demand index (1770 base) grows at a rate of only 1.6 percent. A useful consistency check can be performed on Hoffmann's index. The growth of exports, investment and military expenditure are relatively reliable. These estimates and the relative weights for 1770 can be combined and the consumption growth implied by Hoffmann's index can be calculated as a residual. This calculation reveals that Hoffmann's index implies a near tripling (to 280) of consumption between 1770 and 1815. This consumption growth represents an approximate doubling of consumption of industrial goods per member of the civilian labor force. Consumption growth 
TABLE 9

Indices of Demand for Industrial Goods, 1700-1815

$$
(1841=100)
$$

A. Consumption

\begin{tabular}{|c|c|c|c|c|}
\hline & Real Wage & $\begin{array}{c}\text { per } \\
\text { Worker }\end{array}$ & $\begin{array}{l}\text { Labor } \\
\text { Force }\end{array}$ & Con sumption \\
\hline $\begin{array}{l}1700 \\
1770 \\
1815\end{array}$ & $\begin{array}{l}60 \\
75 \\
75\end{array}$ & $\begin{array}{l}50 \\
67 \\
67\end{array}$ & $\begin{array}{l}37 \\
45 \\
65\end{array}$ & $\begin{array}{l}18 \\
30 \\
44\end{array}$ \\
\hline
\end{tabular}

B. Other Components of Demand

$\begin{array}{lcccc} & \text { Investment } & & \text { Exports } & \text { Military } \\ 1700 & 8 & & 5 & 12 \\ 1770 & 13 & 13 & 39 \\ 1815 & 43 & 43 & 300\end{array}$

C. Indices of Industrial Demand

\begin{tabular}{lccccc} 
& \multicolumn{2}{c}{1841 Base } & \multicolumn{2}{c}{1770 Base } \\
1700 & Index & Rate of Growth & $\frac{\text { Index }}{13}$ & $\frac{\text { Rate of Growth }}{0.8}$ \\
1770 & 25 & 0.8 & 1.4 & 24 & 1.6 \\
1815 & 48 & 2.8 & 48 & 2.8
\end{tabular}

Sources for B: 1. Investment: 1770-1841, Feinstein, "Capital Formation", p. 42; 1700 estimated as some $10 \%$ lower relative to income than Feinstein's 1770 estimate.

2. Exports: 1700-1795: Official values, Mitche11, British Historical Statistics, pp. 279-281; 1795-1841: Tentative volume estimate, Mitchel1, p. 328 .

3. Military: Military budget, Mitche11, pp. 390-91 and 396-97. 
of this magnitude certainly seems inconsistent with most wage estimates.

\section{Industrialization and the Sources of Demand Growth}

The index of industrial production and the index of demand correspond closely and make possible investigation of the sources of demand that were Involved in British industrialization. In the process, the nature of industrial growth will become clearer. Table 10 shows that while rising incomes were an important component of rising demand for industrial products before 1770 and after 1815, that "demand factors"--population size, exports, investment and military demand--accounted for the growth of industrial output during the period of the Industrial Revolution (1770-1815) and were important at other times as well. The importance of these demand factors in industrial growth invites some consideration of the sources of their growth. Much of the growth of consumption may be attributed to the growth of the labor force and that in turn to the growing population. The dynamics of eighteenth century population growth is the subject of a substantial but inconclusive literature and nothing can be added here.

Export growth was a major source of industrial demand growth. Although Deane and Cole assume that the growth of exports was a reflection of industrial development in Britain, presumably through the universal effect of falling prices and the availability of new goods, ${ }^{27}$ this view is highly unlikely. Instead, the growth of British exports can be almost totally explained by population growth in North America and naval successes that opened markets in the Spanish and Portuguese colonies to British trade. From 1730 to the end of the century three-quarters of the increase in exports went to North America and the West Indies, and more than four-fifths of the spectacular export 
TABLE 10

Allocation of Industrial Growth by Sources of Demand, 1700-1841

of Which:

Consumption

Total Growth of Which: ${ }^{2} \quad$ Labor

(\% per year) Total Real Wages Size Exports Investment Military

I. 1841 Base

$\begin{array}{llllllll}1700-1770 & 0.81 \% & 0.57 & (0.46 & 0.21) & 0.15 & 0.05 & 0.04 \\ 1770-1815^{1} & 1.18 & 0.45 & (0.00 & 0.45) & 0.24 & 0.22 & 0.27 \\ 1815-1841^{1} & 2.82 & 2.08 & (1.19 & 0.89) & 0.50 & 0.42 & -0.18\end{array}$

II. 1770 Base

$\begin{array}{lllllllll}1700-1770 & 0.82 & 0.58 & (0.47 & 0.21) & 0.15 & 0.05 & 0.04 \\ 1770-1815^{1} & 1.57 & 0.55 & (0.00 & 0.55) & 0.46 & 0.25 & 0.31 \\ 1815-1841^{1} & 2.79 & 1.83 & (1.04 & 0.79) & 0.73 & 0.39 & -0.16\end{array}$

Notes:

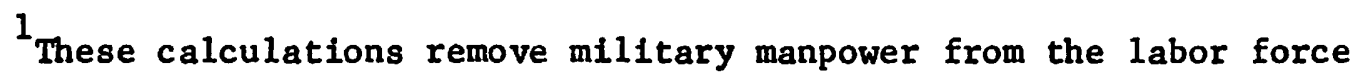
and allocate its consumption to the military sector. A more revealing procedure for many purposes might be to reallocate these men to the labor force and to increase consumption demand proportionally while reducing military by a similar amount. In that case the entries in the table would become:

1841 Base

$\begin{array}{rrrrrrrr}1770-1815 & 1.18 & 0.59 & (0.00 & 0.59) & 0.24 & 0.22 & 0.13 \\ 1815-1841 & 2.82 & 1.93 & (1.19 & 0.74) & 0.50 & 0.42 & -0.03\end{array}$

1770 Base

1770-1815

1.57

$0.68 \quad(0.00$

0.68) $\quad 0.46$

0.25

0.18

1815-1841

2.79

$1.74 \quad(1.04$

$0.70) \quad 0.73$

0.39

$-0.07$

${ }^{2}$ Consumption has been allocated by consumption at base real wage and terminal labor force to labor force size and the balance to real wages. 
growth from 1770 to the end of the century went to those markets. The growth of exports to North America were almost entirely a reflection of population growth there. Between 1710 and 1770 , British exports to North America increased to 8.6 times their initial level while American population increased to over seven times its initial level. From 1770 to the turn of the century, exports to North America kept pace with population growth, each reaching 2.2 times its 1770 level. From 1800 to 1815 population grew more rapidly than exports. 28 The other source of export expansion was the spurt of sales to the West Indies in the last years of the century. This undoubtedly was the effect of British success in selling to the Spanish colonies. The most spectacular increase--exports nearly doubled in 1798 and remained high thereafter--was the result of wartime success. The British naval victory at the Battle of Cape St. Vincent in February 1798 led to a blockade of Cadiz. The Spanish colonies in the New World were cut off from their normal sources of supply and forced to import from Britain through the free parts in the British West Indies. ${ }^{29}$

III. Conclusion: A Revised Plcture of British Growth and Industrialization The principal conclusion that emerges from this investigation of industrial growth in Britain before 1841 is that the growth of industrial production was much slower between 1770 and 1815 than either most accounts of the Industrial Revolution or the quantitative research of Walther Hoffmann and of Phyllis Deane and W. A. Cole have suggested. This conclusions seems fairly secure, resting as it does on both output data and reasonable conjectures about demand growth. The indices imply that the industrial sector in the eighteenth century was nearly twice as large as previous estimates indicated and that its transformation less dramatic. 
As a final exercise, it seems appropriate to bring the se new estimates of industrial production together with other recent revisions, principally by N.F.R. Craft, ${ }^{30}$ of Deane and Cole's estimates and produce some new conjectural estimates of income growth. This is done in Table 11 below. The picture that emerges is one of steady acceleration of per capita income and total productivity. This view of the beginnings of British growth seems more plausible than Deane and Cole's that shows late eighteenth century acceleration and subsequent slowdown. It also seems better supported by available evidence and tests of internal consistency.

Finally, a few speculations about the nature of the growth process are suggested by the evidence that has been presented here. Certainly Mokyr was correct when he asserted that aggregate growth was probably supplyconstrained but Table 10 shows that Gilboy's suggestion that insights into Britain's industrialization were to be gained from an examination of demand appears vindicated. The demand calculations which are able to account for the growth of industrial output estimated with production data without any explicit consideration of price effects from new industrial technology, also suggest that Britain's industrialization may well have been the result of balanced productivity growth throughout the economy. The increasing relative importance of the industrial sector emerged in response to the relatively high income elasticity of demand for industrial products and from the opportunities for increased trade that emerged from growing American population. 
TABLE 11

Estimate of National Income and its Growth 1700-1841

Output Indices

Output Indices

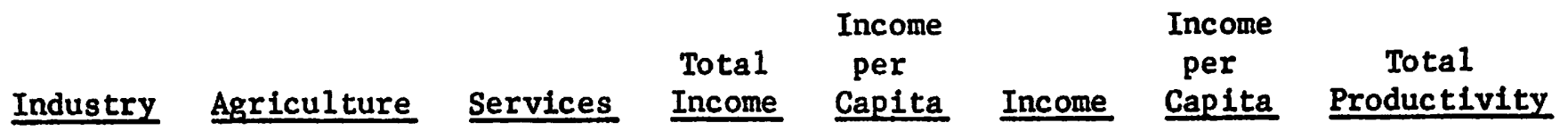

1700

13

34

22

48

68

100

1841
21

30

59

100
21

31

56

100
57

69

0.56

0.27

0.00

80

1.31

0.33

0.25

100

0.86

0.71

Notes and Sources:

1. Industrial Production: Tables 6 and 10.

2. Agriculture: $1700-1770$ assumed growth of $0.5 \%$ per year after Craft, "Engl1sh Growth", 1770-1841, Deane and Cole, pp. 78-170.

3. Services: $1700-1800$ assumed growth of $0.25 \%$ per year in excess of population, 1800-1841: assumed growth of productivity of $0.5 \%$ per year and Deane and Cole, p. 143 employment after Craft, "National Income". 
FOOTNOTES

1"Economic History as a Discipline," Encyclopedia of the Social Sciences, Vo1. V (New York: Macmillan, 1930). Reprinted in Frederic C. Lane and J. C. Riemersma, eds., Enterprise and Secular Change (Homewood, III.: Richard D. Irwin, 1953), P. 416.

2Walther G. Hoffmann, British Industry 1770-1950. Translated by W. O. Henderson and W. H. Chaloner (Oxford; 1955); Phyllis Deane and W. A. Cole, British Economic Growth 1688-1959 (2nd ed. Cambridge, Eng.: Cambridge University Press, 1967), Chs II and V.

3industry and Empire (London: Penguin, 1969), p. 56.

4"Occupations of the People," Journal of the Royal Statistical Society, 1886, pp. $314-435$.

5 British Economic Growth, p. 212.

6"Movements in the Quality of British Cotton Textile Exports, 1815-1913," Journal of Economic History, XXVIII (1968), p. 8.

${ }^{7}$ G. N. von Tunzelmann, Steam Power and British Industrialization to 1860 (Oxford: Clarendon Press, 1978), p. 231.

8"Movement s," p. 24.

9. A. Farnie, The English Cotton Industry and the World Market 1815-1896 (Oxford: Clarendon Press, 1979), Pp. 82-83, states that cotton prices did not fall significant ly before 1800 .

10 Technological Change and the British Iron Industry 1700-1870 (Princeton: Princeton University Press, 1977), pp. 204-206. 
${ }^{11}$ Hyde, British Iron, pp. 127-129, 141.

${ }^{12}$ An alternative aggregation procedure is possible following Deane and Cole (British Growth, p. 222) based on Irving's real values for exports ("Official and Real or Current Values for Imports and Exports of Great Britain to and from Ireland," PP 1803/4, VIII, P. 4). Irving's data for iron exports show the following values

$\begin{array}{ll}\text { Iron bars } & 20 / \text { per cwt } \\ \text { Iron nails } & 35 / 6 \text { per cwt } \\ \text { Pig iron } & £ 8 \text { per ton } \\ \text { Wrought iron } & £ 7.19 \text { per cwt } \\ \text { Wire } & £ 3 \quad \text { per cwt }\end{array}$

The implied value added in converting a ton of pig iron to wrought iron-presumably various final products--is equivalent to just over 12 tons of pig iron. This seems high. An output aggregate valuing cast iron at pig iron prices and finished iron at the average of the nail and wrought iron price grows from 5.7 in 1775 to 16.8 in 1815 and 55.5 in 1841 . That is somewhat slower growth from 1770 to 1815 than calculated in the text.

${ }^{13}$ Both the Fisher and the Divisia index have the property of being first-order approximations of the welfare gain for a single consumer. See W. E. Diewert, "Harberger's Welfare Indicator and Revealed Preference Theory," American Economic Review 66 (March 1976), pp. 143-152.

14 Hoffmann, British Industry, pp. 17-19.
15 The weighting, particularly of cotton, is crucial to this issue. It is perhaps worth noting David MacPherson's estimate of industrial output for 1783 (Annals of Commerce, Vol. IV, New York, Johnston Reprint, 1972 (originally published 1805), p. 1546). His enumeration, which excludes building and food and drink (20 to 25 percent of the total) weighs cotton at just under 2 percent and iron at 23 percent of the total. 
${ }^{16}$ On domestic consumption see Elizabeth W. Gilboy, "Demand as a Factor in the Industrial Revolution," in A. H. Cole, ed., Facts and Factors in Economic History (Cambridge, Mass., 1932); A. H. John, "Aspects of English Economic Growth in the First Half of the Eighteenth Century," Economica 1961, and "Agricultural Productivity and Economic Growth in England, 1700-1760," Journal of Economic History, 25 (1965); and D. E. C. Eversley, "The Home Market and Economic Growth in England, 1750-1780," in E. L. Jones and G. E. Minagay, eds., Land, Labour and Population in the Industrial Revolution (Lonđon, 1967).

For military demand see A. H. John, "War and the English Economy, 1700-1763," The Economic History Review, 2nd. ser., 7 (1955). For exports see Ralph Davis, "English Foreign Trade, 1700-1774," The Economic History Revicw, 2nd. ser., 15 (1962).

${ }^{17}$ See Richard A. Ippolito, "The Effect of the Agricultural Depression on Industrial Demand in England, 1730-1750," Economica 42 (Aug. 1975) and Joel Mokyr, "Demand vs. Supply in the Industrial Revolution," Journal of Economic History 37 (Dec. 1977).

18 British Growth, p. 166.

${ }^{19} \mathrm{C} . \mathrm{H}$. Feinstein, "Capital Formation in Great Britain," Ch. II in Peter Mathias and M. M. Postan, eds., The Cambridge Economic History of Europe, Vol. VII, The Industrial Economies: Capital, Labour, and Enterprise (Cambridge: Cambridge University Press, 1978). 
${ }^{20}$ Robert E. Gallman's work with the nineteenth century U.S. Censuses which contain data on sales and value added indicate value added as about 70 percent of sales. "Commodity Output, 1839-1899," in N.B.E.R. Trends in the American Economy in the Nineteenth Century, Studies in Income and Wealth, Vol 24 (New York, 1960), pp. 59-60, and "Gross National Product in the United States, 1834-1909," in N.B.E.R., Output, Employment and Productivity in the United States After 1800, Studies in Income and WeaIth, No. 30 (New York, 1966), pp. 46-7 indicate that in 1839 the value of final sales of manufactured goods was $\$ 345$ million and the value added in manufacturing was $\$ 250$ million. Value added exceeds income originating in the sector. Twentieth century data, Historical Statistics of the United States: Colonial Times to 1957 (Washington, 1960), P. 402 and Series P8 and F26, indicate between 70 and 75 of value added is income originating.

${ }^{21}$ This would be a major undertaking. The interested scholar would start with the summary of the various parliamentry investigations in "Public Income and Expenditures from 1688; Appendix 13 to Part II: "Explanation and Historical Notices of the Several Heads of Public Income and Expenditure," pp. 669-700. PP 1868/9 XXXV; and also Richard Clover, Peninsular Preparation: Reform of the British Army 1795-1809 (Cambridge: Cambridge University Press, 1963).

${ }^{22}$ Michacl Glover, Wellington's Army in the Peninsula 1808-1814 (Newton Abbott: David and Charles, 1977), Ch. 8, c.f. p. 107.

23M. W. Flinn, "Trends in Real Wages, 1750-1850," The Economic History Review 27 (1974). These data have recent ly been reanalyzed by sophisticated tcchniques in G. N. von Tunzelmann, "Trends in Real Wages, 1750-1850, Revisited,," The Economic History Review, 2nd ser. 32 (1979). von Tunzelmann's analysis reemphasizes the fragility of these data but does not contradict the assumption here. 
24 Wages in the Eighteenth Century (Cambridge, Mass., 1934) and Deane and Cole, p. 19. I have used Deane and Cole's "general average".

${ }^{25}$ There are recent estimates presented by Ron Lee, "British Population in the Eighteenth Century," at the Conference of the Economic History of Britain at Cambridge, England in December 1976. Forthcoming in Roderick Flood and Donald N. McCloskey, eds., Economic History of Britain (Cambridge: Cambridge University Press, 1981).

${ }^{26}$ For evidence of demand elasticities, see, for example, H. Houthakker, "An International Comparison of Household Expenditure Patterns Commemorating the Centenary of Engel's Law," Econometrica 25 (1957). Cross-sectional investigations also show a relationship between the level of per capita income and the size of the manufacturing sector. See Hollis B. Chenery, "Patterns of Industrial Growth," American Economic Review 50 (1960) cf. p. 634 and Simon Kuznets, Economic Growth of Nations (Cambridge, Mass., 1971), Chs. III and IV, cf. p. 111. The choice of an income elasticity of 1.4 represents the choice at the high end of the range of reasonable values. This choice has the result of causing a more rapid growth of estimated demand than would have been the case if a lower elasticity were used.

27 Little has been said in this paper about Deane and Cole's estimate of industrial output. In broad outline it is not dissimilar to Hoffmann's but its construction is quite different. In particular the eighteenth century index is a composite of several excise series for "Home Industries" and trade aggregates as a proxy for "Export Industries". These are combined with relative weights for 1700 of forty and sixty percent (British Growth, pp. 75-82). The rapid growth of the index after 1780 is solely a reflection of the growth of trade. 
${ }^{28}$ Population estimates are from Historical Statistics of the United States, pp. 758,757 . The $1797 / 98$ data include $.5 \mathrm{~m}$ for the area to become the Dominion of Canada (see Colin McEvedy and Richard Jones, Atlas of World Population History (London 1978), p. 285.

Exports are from Jacob M. Price, "Net Time Series for Scotland's and Britain's Trade with the Thirteen Colonies and States, 1740-1791," William and Mary Quarterly 32 (1975), pp. 324-325; and Deane and Cole, British Growth, p. 87. 29 See Frances Armytage, The Free Port System in the British West Indies (London, 1953), Chs. I and VI. Also see D. C. M. Platt, Latin America and British Trade, 1806-1914 (London, 1972), Ch. 1. 30 N. F. R. Craft, "English Economic Growth in the Eighteenth Century: A Re-Examination of Deane and Cole's Estimates," The Economic History Review XXIX (May 1976), pp. 226-235, and "NationaI Income Estimates and the British Standard of Living Debate: A Reappraisal of 1801-1831," Explorations in Economic History 17 (April 1980), pp. 176-188. 